\title{
30. LIPID GEOCHEMISTRY OF THE CRETACEOUS/TERTIARY BOUNDARY SEDIMENTS, HOLE 577, DEEP SEA DRILLING PROJECT LEG 86 ${ }^{1}$
}

\author{
Bernd R. T. Simoneit and Harry R. Beller, Oregon State University ${ }^{2}$
}

\begin{abstract}
Core samples of calcareous sediments taken from above and below the proposed Cretaceous/Tertiary boundary (Sample 577-12-5, $130 \mathrm{~cm}$ ) were examined for geochemical evidence of the mass extinctions and faunal successions that marked this period. The lipid compositions of the six core samples examined were virtually identical and were characterized by a large component of unresolved naphthenic hydrocarbons and a homologous series of anteiso-alkanes, both presumably of bacterial origin. The results of this preliminary study suggest that the lipids of sediments deposited over a several million year period encompassing the Cretaceous-Tertiary extinctions have been almost completely recycled by bacterial metabolism, which occurred under oxic depositional and/or diagenetic conditions and which left a unique bacterial signature with only minor traces of the original sedimentary lipids.
\end{abstract}

\section{INTRODUCTION}

The Cretaceous/Tertiary boundary is marked by major extinctions of both marine and terrestrial species. These extinctions were probably caused by the impact of a massive extraterrestrial body (Alvarez et al., 1980, 1984), which was of meteoritic origin according to current data on Ir and Os anomalies (Alvarez et al., 1982, 1984; Luck and Turekian, 1983). A major meteoritic impact could have had extensive biogeochemical consequences, such as the cessation or dramatic reduction of photosynthetic biomass production on a regional to global scale and the scouring of continents by tidal waves. Presumably, a reduction of biogenesis, a possible hiatus or facies change at the Cretaceous/Tertiary boundary, and a subsequent, gradual buildup of extant and new species should have left a molecular fossil record in the sediments. The purpose of this preliminary analysis is to evaluate such a possibility.

The samples for this study are derived from Hole 577, Core 12, located on the Shatsky Rise in the western $\mathrm{Pa}$ cific Ocean $\left(32^{\circ} 26.51^{\prime} \mathrm{N}, 157^{\circ} 43.40^{\prime} \mathrm{E}, 2675 \mathrm{~m}\right.$ water depth) (Site 577 chapter, this volume). The sediment of Core 12 consists of white calcareous nannofossil ooze with very low organic carbon content. The Cretaceous/ Tertiary boundary was tentatively assigned at Sample $577-12-5,118 \mathrm{~cm}$ on board ship and was more accurately determined by shore-based work to be at Sample $577-12-5,130 \mathrm{~cm}$ (Monechi, this volume; Site 577 chapter, this volume). No iridium measurements were made in Hole 577, Core 12 sediments, but an iridium anomaly has been determined to occur in adjacent Hole 577B at the Cretaceous/Tertiary boundary (Sample 577B-1-4, 72 $\mathrm{cm}$ ) (Michel et al., this volume). The samples for this work were chosen prior to the readjustment of the Cretaceous/Tertiary boundary and the two samples from below the boundary were combined.

\footnotetext{
${ }^{1}$ Heath, G. R., Burckle, L. H., et al., Init. Repts. DSDP, 86; Washington (U.S. Govt. Printing Office),

2 Address: College of Oceanography, Oregon State University, Corvallis, OR 97331.
}

\section{METHODS}

The samples were freeze-dried and then exhaustively extracted with methylene chloride using ultrasonic agitation. The extracts were concentrated on a rotary evaporator and treated with diazomethane in diethyl ether to derivatize free fatty acids. These total extracts were then subjected directly to gas chromatography $(\mathrm{GC})$ and gas chromatography-mass spectrometry (GC-MS).

The GC analyses were carried out on a Varian Vista 44 gas chromatography system using a $30 \mathrm{~m} \times 0.25 \mathrm{~mm}$ fused silica capillary column coated with DB-1701 (J and W Scientific, Inc.) and programmed from 65 to $275^{\circ} \mathrm{C}$ at $10^{\circ} \mathrm{C} / \mathrm{min}$. Helium was the carrier gas.

The GC-MS analyses were performed on a Finnigan 4021 quadrupole mass spectrometer interfaced directly to a Finnigan 9610 gas chromatograph, equipped with a $30 \mathrm{~m} \times 0.25 \mathrm{~mm}$ fused silica capillary column coated with DB-5. The GC for the GC-MS analyses was programmed from 60 to $310^{\circ} \mathrm{C}$ at $4^{\circ} \mathrm{C} / \mathrm{min}$. The mass spectrometric data were acquired and processed with a Finnigan-Incos 2300 data system.

Total organic carbon values were determined for samples above and below the Cretaceous/Tertiary boundary (Samples 577-12-5, 120$121 \mathrm{~cm}$ and $132-134$ plus $147-149 \mathrm{~cm}$ ) by the phosphoric acid/dichromate oxidation technique (procedure described in Weliky et al., 1983).

\section{RESULTS AND DISCUSSION}

The total extract yields, the total concentrations of anteiso-alkanes and the lithologies and ages of the samples are given in Table 1 . The total organic carbon contents of the samples tested were below $0.05 \%$ (as $\%$ dry wt. of sediment) and were thus considered too low for meaningful quantitative comparison among samples. The extract yields are low and consist mainly of unresolvable naphthenic hydrocarbons (hump), as indicated in the gas chromatograms of Figure 1. There is no major change in the lipid data across the Cretaceous/Tertiary boundary, although the sample below has a relatively low total extract yield. The GC traces are essentially identical for all samples (i.e., the same peaks are present), with only minor differences in relative peak concentrations. Not all of the minor peaks could be identified by GC-MS analyses.

The major resolved compounds are anteiso-alkanes (some sample distributions are shown in Fig. 2) with lesser amounts of iso-alkanes. Normal alkanes are not detectable and pristane $(\mathrm{Pr})$ and phytane $(\mathrm{Ph})$ are present as minor components, with $\mathrm{Pr}>\mathrm{Ph}$. This ratio of $\mathrm{Pr} /$ 
Table 1. Lipid yields for samples across the Cretaceous/Tertiary boundary in Hole 577.

\begin{tabular}{|c|c|c|c|c|}
\hline $\begin{array}{c}\text { Sample } \\
\text { (interval in } \mathrm{cm} \text { ) }\end{array}$ & $\mathrm{Age}^{\mathrm{a}}$ & Lithology & $\begin{array}{c}\text { Total } \\
\text { extract } \\
\text { yield } \\
(\mu \mathrm{g} / \mathrm{g})^{\mathrm{b}}\end{array}$ & $\begin{array}{c}\text { Total } \\
\text { anteiso-alkanes } \\
\text { (\% of total } \\
\text { extract) }\end{array}$ \\
\hline $577-12-1,21-23$ & $\begin{array}{c}\text { early } \\
\text { Paleocene }\end{array}$ & $\begin{array}{c}\text { Nannofossil } \\
\text { ooze }\end{array}$ & 11.7 & 9.7 \\
\hline $577-12-5,72-74$ & $\begin{array}{c}\text { early } \\
\text { Paleocene }\end{array}$ & $\begin{array}{l}\text { Nannofossil } \\
\text { ooze }\end{array}$ & 5.6 & 7.5 \\
\hline $577-12-5,100-102$ & $\begin{array}{c}\text { early } \\
\text { Paleocene }\end{array}$ & $\begin{array}{c}\text { Nannofossil } \\
\text { ooze }\end{array}$ & 8.1 & 6.8 \\
\hline $577-12-5,111-113$ & $\begin{array}{c}\text { early } \\
\text { Paleocene }\end{array}$ & $\begin{array}{l}\text { Nannofossil } \\
\text { ooze }\end{array}$ & 8.8 & 6.8 \\
\hline $577-12-5,120-121$ & $\begin{array}{c}\text { early } \\
\text { Paleocene }\end{array}$ & $\begin{array}{l}\text { Nannofossil } \\
\text { ooze }\end{array}$ & 9.3 & 5.6 \\
\hline $577-12-5,132-134+147-149$ & $\begin{array}{c}\text { Late } \\
\text { Cretaceous }\end{array}$ & $\begin{array}{l}\text { Nannofossil } \\
\text { ooze }\end{array}$ & 2.1 & 11 \\
\hline
\end{tabular}

${ }^{a}$ Monechi (this volume).

$\mathrm{b}$ Based on dry weight of sediment.

$\mathrm{Ph}>1$, coupled with the absence of elemental sulfur, appears to indicate an oxic depositional environment or at least oxidizing diagenetic conditions (Didyk et al., 1978). The overall compound distribution patterns and the range of the hump indicate that these extracts represent a residue of relatively unaltered bacterial lipids superimposed on degraded algal lipid detritus (Simoneit, 1981, 1982). This microbial lipid origin is further supported by the $n$-fatty acid distributions (Fig. 2), which range from $\mathrm{C}_{14}$ to $\mathrm{C}_{18}$ with a strong even carbon number predominance, typical for microbial sources (Simoneit, 1981, 1982).

The molecular markers are sparse in these samples. Triterpenoids, extended tricyclic terpanes and acyclic isoprenoids $\left(>C_{20}\right)$, all of microbial origin (Simoneit, 1978; Aquino Neto et al., 1982; Chappe et al., 1982), are not detectable in these samples. Traces of steranes are identifiable in two samples above the Cretaceous/Tertiary boundary (Samples 577-12-5, 100-102 $\mathrm{cm}$ and 120-121 $\mathrm{cm}$ ), where the dominant homologs are diasteranes, with a minor series of steranes. $20 S-\beta, \alpha$-diacholestane $20 R$ $\beta, \alpha$-diacholestane are the dominant homologs and occur in a ratio of $S / R=1.4$, indicating that these samples are quite mature (Ensminger et al., 1978). The dominance of the various $\mathrm{C}_{27}$ homologs may indicate an origin from marine algal detritus (Huang and Meinschein, 1979; Simoneit et al., 1980). In addition, there are various diterpenoid residues and alkyl phenanthrenes present, which could be derived from terrestrial higher plant resins or possibly from algal diterpenoids (Simoneit, 1977, and unpublished data). Methyl-, dimethyl- (possibly pimanthrene), and a $\mathrm{C}_{4}$-phenanthrene are present as major components in all samples and dehydroabietic acid, $4 \alpha$ - and $4 \beta$-dehydroabietin, and a nordehydroabietin are found as minor constituents only in samples above the Cretaceous/Tertiary boundary. The low degree of structural preservation of these diterpenoid residues again indicates an oxic depositional environment.

The overall compound distributions in these lipids indicate an origin from bacteria with minor detrital residues from algae and possibly resinous vascular plants. However, we can offer no explanation for the absence of $n$-alkanes and hopanoids or for the low observed concentrations of $n$-fatty acids, which are all normally significant constituents of bacterial lipids. The possibility of contamination by petroleum product lubricants is unlikely, based mainly on the predominance of the anteisoalkanes and additional specific molecular markers indicative of a syngenetic and biological origin for the lipids.

\section{CONCLUSIONS}

The lipid compositions for all samples examined across the Cretaceous/Tertiary boundary are essentially the same. Trace molecular markers are present that indicate a component from algae and, above the Cretaceous/Tertiary boundary, possibly also from terrestrial resinous plants. However, a definitive assignment of the original lipid sources (i.e., algal communities, terrestrial influx) of these samples is not possible, since the residues preserved in the sediments are derived predominantly from bacteria, which efficiently metabolized the other lipids in an oxic environment. Thus, molecular stratigraphy cannot be applied definitively across the Cretaceous/Tertiary boundary because bacterial alteration of the organic detritus has resulted in the preservation of its own unique lipid signature throughout the interval examined here. Changes in ecosystem lipid signatures may be better observed in sediments with enhanced preservation of organic matter and less microbial alteration, that is, in sediments deposited under more euxinic conditions.

\section{ACKNOWLEDGMENTS}

We thank James M. Brooks and an anonymous reviewer for reviewing this manuscript.

\section{REFERENCES}

Alvarez, L. W., Alvarez, W., Asaro, F., and Michel, H. V., 1980. Extraterrestrial cause for the Cretaceous-Tertiary extinction. Science, 208:1095-1108.

Alvarez, W., Alvarez, L. W., Asaro, F., and Michel, H. V., 1982. Current status of the impact theory for the terminal Cretaceous extinction. Geol. Soc. Am., Spec. Pap., 190:305-315.

Alvarez, W., Kauffman, E. G., Surlyk, F., Alvarez, L. W., Asaro, F., and Michel, H. V., 1984. Impact theory of mass extinctions and the invertebrate fossil record. Science, 223(4641):1135-1141. 
Aquino Neto, F. R., Restle, A., Connan, J., Albrecht, P., and Ourisson, G., 1982. Novel tricyclic terpanes $\left(\mathrm{C}_{19}, \mathrm{C}_{20}\right)$ in sediments and petroleums. Tetrahedron Lett., pp. 2027-2030.

Chappe, B., Albrecht, P., and Michaelis, W., 1982. Polar lipids of archaebacteria in sediments and petroleums. Science, 217:65-66.

Didyk, B. M., Simoneit, B. R. T., Brassell, S. C., and Eglinton, G., 1978. Organic geochemical indicators of paleoenvironmental conditions of sedimentation. Nature (London), 272:216-222.

Ensminger, A., Joly, G., and Albrecht, P., 1978. Rearranged steranes in sediments and crude oils. Tetrahedron Lett., pp. 1575-1578.

Huang, W. Y., and Meinschein, W. G., 1979. Sterols as ecological indicators. Geochim. Cosmochim. Acta, 43:739-745.

Luck, J. M., and Turekian, K. K., 1983. Osmium 187/Osmium 186 in manganese nodules and the Cretaceous-Tertiary boundary. Science, 222:613-615.

Simoneit, B. R. T., 1977. Diterpenoid compounds and other lipids in deep-sea sediments and their geochemical significance. Geochim. Cosmochim. Acta, 41:463-476.

1978. The organic chemistry of marine sediments. In Riley, J. P., and Chester, R. (Eds.), (Vol. 7, 2nd ed.): Chemical Oceanography, New York (Academic Press), 233-311.
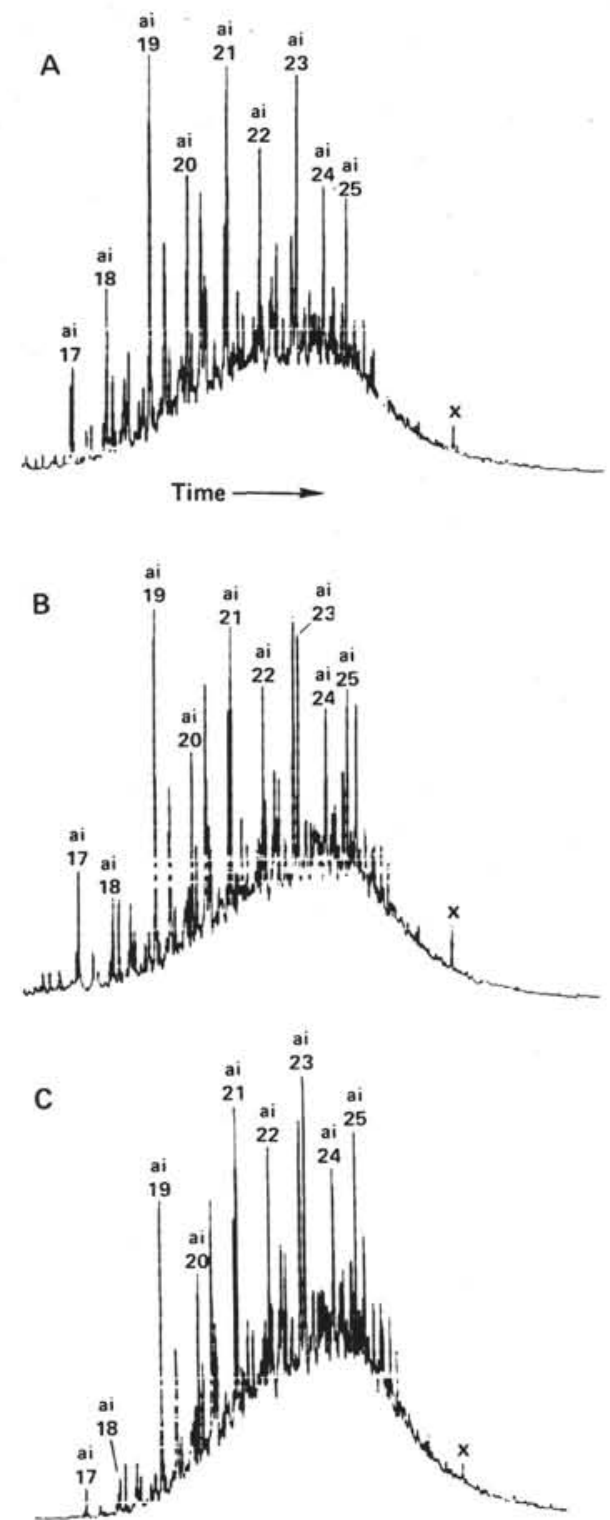

1981. Utility of molecular markers and stable isotope compositions in the evaluation of sources and diagenesis of organic matter in the geosphere. In Prashnowsky, A. A. (Ed.), The Impact of the Treibs' Porphyrin Concept on the Modern Organic Geochemistry: Würzburg (Universität Würzburg), pp. 133-158.

1982. The composition, sources, and transport of organic matter to marine sediments-The organic geochemical approach. In Thompson, J. A. J., and Jamieson, W. D. (Eds.), Proc. of the Symposium Marine Chemistry into the Eighties: Ottawa (Nat. Res. Council of Canada), pp. 82-112.

Simoneit, B. R. T., Halpern, H. I., and Didyk, B. M., 1980. Lipid productivity of a high Andean Lake. In Trudinger, P. A., Walter, M. R., and Ralph, B. J. (Eds.), Biogeochemistry of Ancient and Modern Environments: New York (Springer Verlag), pp. 201-210.

Weliky, K., Suess, E., Ungerer, C. A., Muller, P. J., and Fischer, K., 1983. Problems with accurate carbon measurements in marine sediments and particulate matter in seawater: A new approach. Limnol. Oceanogr., 28:1252-1259.

Date of Initial Receipt: 11 May 1984 Date of Acceptance: 11 July 1984

D
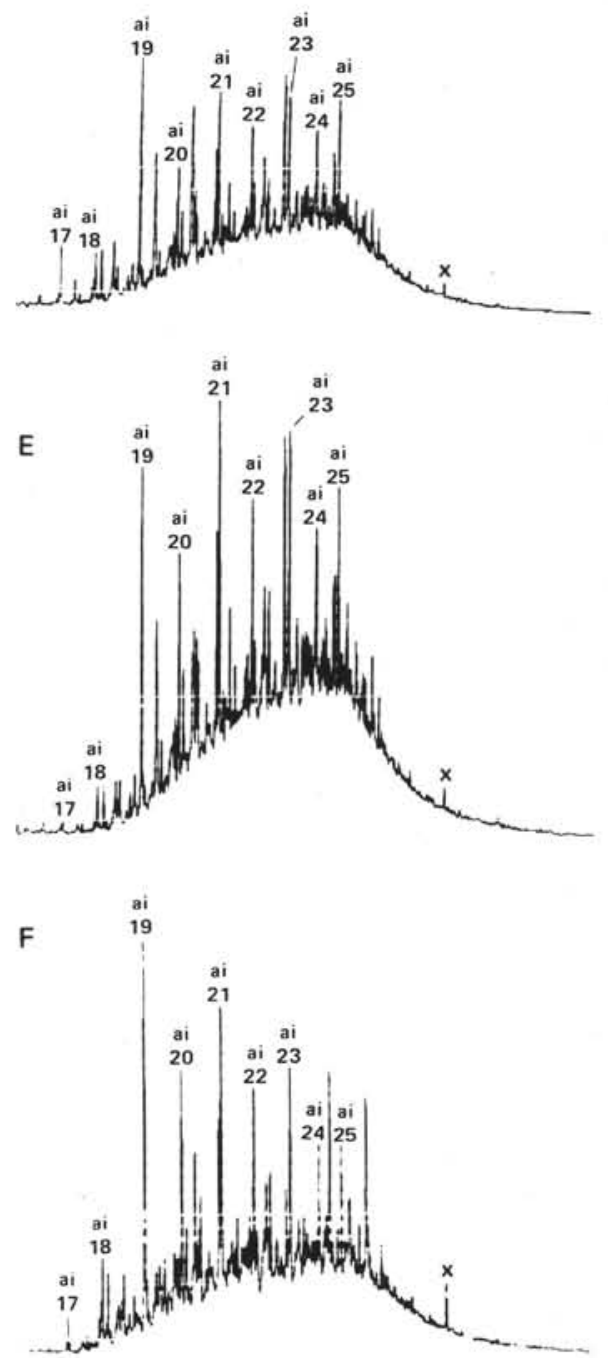

Figure 1. Capillary gas chromatograms of total extract fractions (GC conditions as in text). (A) Sample 577-12-1, 21-23 cm; (B) Sample 577-12-5, 72-74 cm; (C) Sample 577-12-5, 100-102 cm; (D) Sample 577-12-5, 111-113 cm; (E) Sample 577-12-5, 120-121 cm; (F) Sample 577-12-5, 132-134 and 147-149 $\mathrm{cm}$. (Arabic numerals indicate carbon number of anteiso-alkanes, $x=\mathrm{C}_{8}$-phthalate contaminant). 
B. R. T. SIMONEIT, H. R. BELLER
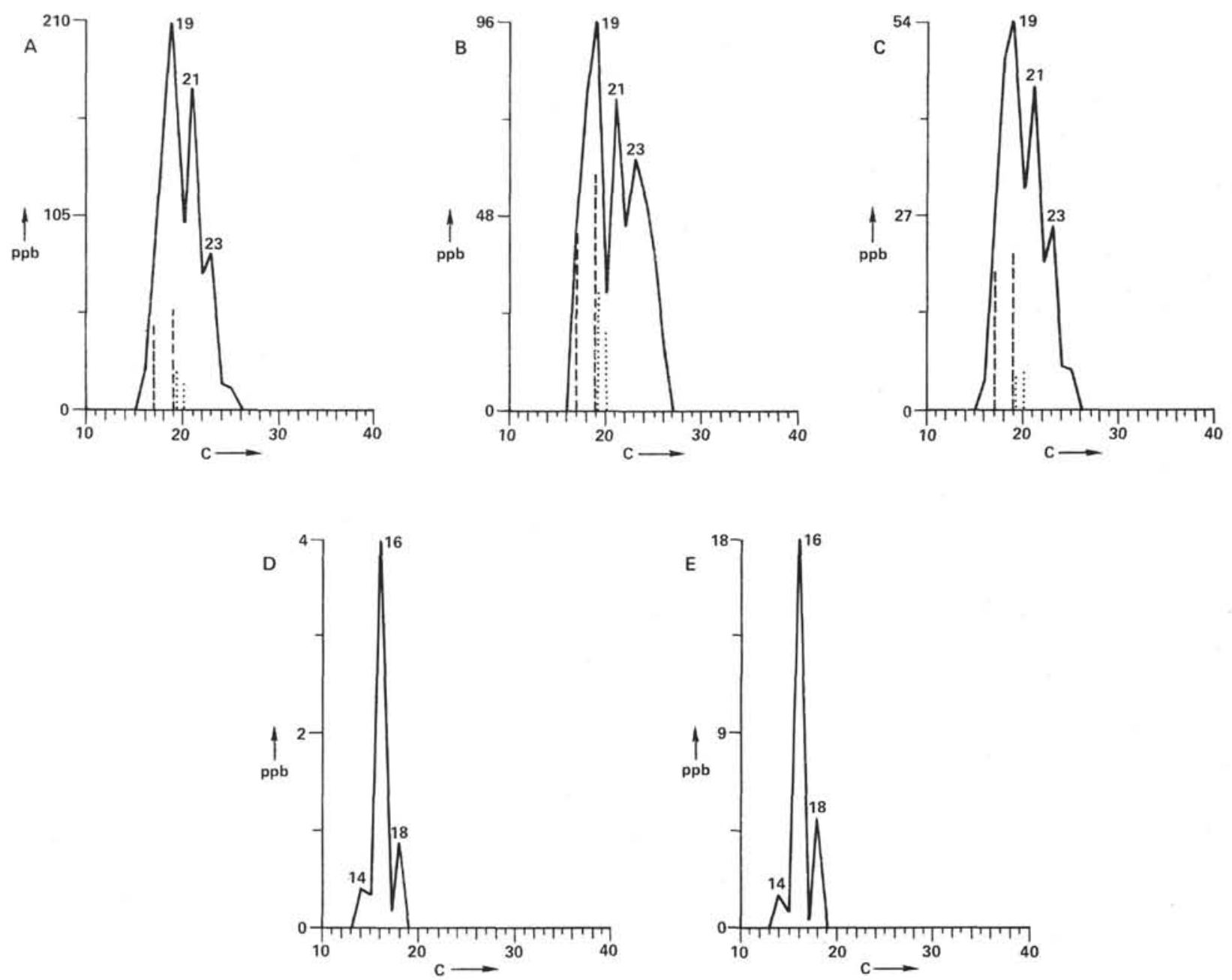

Figure 2. Distribution diagrams of typical hydrocarbon and fatty acid series in the extracts. (A-C) Anteiso-alkanes (dashed line, iso-alkanes, dotted line, isoprenoids) and (D, E) $n$-fatty acids: (A) Sample 577-12-1, 21-23 cm; (B) Sample 577-12-5, 120-121 cm; (C) Sample 577-12-5, 132-134 and 147-149 cm; (D) Sample 577-12-5, 100-102 cm; (E) Sample 577-12-5, 132-134 and 147-149 cm. 